\title{
Periodate-treated, non-anticoagulant heparin-carrying polystyrene (NAC-HCPS) affects angiogenesis and inhibits subcutaneous induced tumour growth and metastasis to the lung
}

\author{
K Ono', M Ishihara*,2, K Ishikawa ${ }^{3}$, Y Ozeki', H Deguchi', M Sato', H Hashimoto', Y Saito ${ }^{4}$, H Yura ${ }^{4}$, A Kurita ${ }^{2}$ \\ and T Maehara'
}

'Department of Surgery II, National Defense Medical College, 3-2, Namiki, Tokorozawa, Saitama, 359-85 I 3 Japan; ${ }^{2}$ Research Institute, Division of Biomedical Engineering, National Defense Medical College, 3-2, Namiki, Tokorozawa, Saitama, $359-8513$ Japan; ${ }^{3}$ Department of Surgery I, National Defense Medical College, 3-2, Namiki, Tokorozawa, Saitama, 359-85 I 3 Japan; ${ }^{4}$ NeTech Inc., KSP East Wing 502, Sakado 3-2-I, Takatsu, Kawasaki, Kanagawa 2/3-00/2, Japan

Periodate-treated, non-anticoagulant heparin-carrying polystyrene consists of about ten periodate-oxidized, alkaline-degraded low molecular weight-heparin chains linked to a polystyrene core and has a markedly lower anti-coagulant activity than heparin. In this study, we evaluated the effect of non-anticoagulant heparin-carrying polystyrene on tumour growth and metastasis. Non-anticoagulant heparin-carrying polystyrene has a higher activity to inhibit vascular endothelial growth factor165-, fibroblast growth factor-2- or hepatocyte growth factor-induced human microvascular endothelial cell growth than heparin, ten periodate-oxidized-heparin and ten periodate-oxidized-low molecular weight-heparin, which is probably due to the heparin-clustering effect of non-anticoagulant heparin-carrying polystyrene. Non-anticoagulant heparin-carrying polystyrene inhibited human microvascular endothelial cell, BI6 melanoma and Lewis lung cancer cell adhesion to Matrigel-coated plates. Non-anticoagulant heparin-carrying polystyrene also showed strong inhibitory activities in the tubular formation of endothelial cells on Matrigel and BI6-melanoma and Lewis lung cancer cell invasion in a Matrigel-coated chamber assay. In vivo studies showed that growth of subcutaneous induced tumours and lung metastasis of B16-melanoma and Lewis lung cancer cells were more effectively inhibited by non-anticoagulant heparin-carrying polystyrene than ten periodate-oxidized-heparin and ten periodate-oxidized-low molecular weight-heparin. Furthermore, non-anticoagulant heparin-carrying polystyrene markedly reduced the number of CD34-positive vessels in subcutaneous Lewis lung cancer tumours, indicating a strong inhibition of angiogenesis. These results suggest that non-anticoagulant heparin-carrying polystyrene has an inhibitory activity on angiogenesis and tumour invasion and may be very useful in cancer therapy.

British Journal of Cancer (2002) 86, I803- 1812. doi: 10.1038/sj.bjc.6600307 www.bjcancer.com

(c) 2002 Cancer Research UK

Keywords: periodate-treated; non-anticoagulant heparin-carrying polystyrene (NAC-HCPS); heparin; angiogenesis; metastasis; tumour growth

Heparin (Hep)/heparan sulphate (HS) are members of the glycosaminoglycans (GAGs) and are normally present as proteoglycans (PGs), in which a number of Hep/HS-chains are covalently attached to a core protein. While HS is widely distributed on cell surfaces and in extracellular matrices in most animal tissues, Hep is synthesised by mast cells in connective tissue and stored in cytoplasmic granules (Ishihara and Ono, 1998). Heparin is isolated on a commercial basis from animal tissue (pig or bovine intestinal mucosa, or bovine lung etc.) and has been extensively used as an anti-thrombotic drug for a long time (Ishihara and Ono, 1998). The biological role of Hep/HS is highly diverse. Aside from its well-known anti-coagulant action, the molecules are found to be associated with growth factors and cytokines in various biological processes, as well as being involved in cell adhesion, recognition,

*Correspondence: M Ishihara; E-mail: ishihara@res.ndmc.ac.jp Received 3I December 200 I; revised 12 March 2002; accepted I4 March 2002 migration, and regulation of various enzymatic activities (Lindahl et al, 1994; Kjellen and Lindahl, 1991).

Several studies have reported both inhibitory and stimulatory effects of Hep on tumour growth and metastasis (Zacharski and Ornstein, 1998; Engelberg, 1999; Smorenburg and Van Noorden, 2001). Besides the anticoagulant function, Hep binds to various growth factors, cytokines, and extracellular matrix (ECM) proteins and consequently is able to affect proliferation and migration of cancer cells and angiogenesis in tumours (Lindahl et al, 1994). Furthermore, Heps have been found to inhibit expression of oncogenes and to affect the immune system (Smorenburg and Van Noorden, 2001). Heparins also show both inhibitory and stimulatory effects of various proteolytic enzymes, which are essential for invasion of cancer cells and angiogenesis through the ECM (Zacharski and Ornstein, 1998; Engelberg, 1999; Smorenburg and Van Noorden, 2001). Due to the wide variety of activities of Heps, the ultimate effect of a Hep treatment on cancer progression is unpredictable. In addition, the use of a high-dose Hep has been limited by its strong anti-coagulant property, which may cause severe bleeding complications (Levine et al, 1989; Lapierre et al, 1996). 
Periodate-treated, non-anticoagulant Hep-carrying polystyrene (NAC-HCPS) has been described previously as a synthetic glycoconjugate that is soluble in water and has an amphiphilic structural unit consisting of hydrophilic polysaccharides and hydrophobic polystyrene moieties (Ishihara et al, 2000a). It has been estimated that the molecular size of NAC-HCPS is approximately 80$120 \mathrm{kDa}$ and comprises of over ten periodate-oxidised, alkalinedegraded low molecular weight $\left(\mathrm{IO}_{4}\right.$-LMW-) Hep chains enriched in trisulphated disaccharide structures linked to its polystyrene core (Ishihara et al, 2000a,b). Non-anticoagulant Hep-carrying polystyrene shows a significantly reduced anticoagulant activity and enhanced abilities to interact with various heparin-binding growth factors, such as fibroblast growth factor-2 (FGF-2), vascular endothelial growth factor-165 $\left(\mathrm{VEGF}_{165}\right)$ and hepatocyte growth factor (HGF), which are known to stimulate angiogenesis (Ishihara et al, 2000b).

The present study evaluates the effect of NAC-HCPS on malignant processes in vitro and in vivo, thereby focusing on angiogenesis. Non-anticoagulant Hep-carrying polystyrene inhibit, (i) heparin-binding growth factor-induced human microvascular endothelial cell (HMVEC) proliferation, (ii) HMVEC adhesion onto Matrigel, (iii) formation of capillary-like tubular structures on Matrigel by HMVECs in vitro, and (iv) vascularisation in tumour tissue in vivo. In addition, NAC-HCPS is an inhibitor for experimental subcutaneous tumour growth and metastasis to the lung using B16 melanoma (B16) and Lewis lung cancer (3LL) cells.

\section{MATERIALS AND METHODS}

\section{Preparation of modified Heps and NAC-HCPS}

Non-anticoagulant Hep-carrying polystyrene was prepared as has been reported previously (Ishihara et al, 2000a). An outline of the used chemical reaction route to synthesise modified heparins and NAC-HCPS is presented in Figure 1. Briefly, $25 \mathrm{~g}$ of Hep from porcine intestine (185.8 USP Units $\mathrm{mg}^{-1}$ ) dissolved in $400 \mathrm{ml}$ of $0.1 \mathrm{M} \mathrm{NaIO}_{4}$ in $0.05 \mathrm{M}$ sodium acetate buffer ( $\mathrm{pH} 5$ ) was stirred at $4{ }^{\circ} \mathrm{C}$ for 3 days. The unreacted $\mathrm{NaIO}_{4}$ was then neutralised by addition of glycerol $(25 \mathrm{ml})$, and the reaction mixture was subsequently dialysed and lyophilised. The product (non-reduced periodate-oxidised heparin; non-reduced $\mathrm{IO}_{4}$-Hep) was then degraded in an alkaline solution ( $\mathrm{pH} 12)$ at room temperature for $30 \mathrm{~min}$, and the degraded product was recovered after dialysis and lyophilisation as non-reduced periodate-oxidised, alkalinedegraded (non-reduced $\mathrm{IO}_{4}-\mathrm{LMW}-$ ) Hep. To prepare reduced $\mathrm{IO}_{4}$-Hep and reduced $\mathrm{IO}_{4}$-LMW-Hep as control compounds in order to compare with NAC-HCPS, both non-reduced $\mathrm{IO}_{4}-\mathrm{Hep}$ and non-reduced $\mathrm{IO}_{4}$-LMW-Hep were reduced by mixing them with $0.2 \mathrm{M}$ sodium borohydride in $0.25 \mathrm{M}$ sodium bicarbonate for $3 \mathrm{~h}$ at $4^{\circ} \mathrm{C}$. The excess borohydride in both reactions was destroyed by adding acetic acid ( $\mathrm{pH} 5)$. The reduced $\mathrm{IO}_{4}-\mathrm{Hep}$ and reduced $\mathrm{IO}_{4}$-LMW-Hep were then recovered after neutralising with $\mathrm{NaOH}$, dialysis and lyophilisation.

The non-reduced $\mathrm{IO}_{4}$-LMW-Hep $(500 \mathrm{mg})$ and $p$-styrenemethylamine $(250 \mathrm{mg})$ were dissolved in $20 \mathrm{ml}$ of $50 \mathrm{~mm} N, N, N^{\prime}, N^{\prime}$ tetramethyl-ethylenediamine ( $\mathrm{pH} 4.75)$, after which $1 \mathrm{ml}$ of $0.8 \mathrm{~mm} \mathrm{NaCNBH}$ was added. The reaction mixture was stirred for $24 \mathrm{~h}$ at room temperature, dialysed and lyophilised to yield a white powder (heparin-styrene monomer). This powder $(100 \mathrm{mg})$ and $2 \mathrm{mg}$ of potassium peroxodisulphate were dissolved in $1 \mathrm{ml}$ of distilled water and the polymerisation was carried out at $60^{\circ} \mathrm{C}$ for $24 \mathrm{~h}$ under dried $\mathrm{N}_{2}$ gas. The reaction solution was then slowly poured into an excess amount of ethanol to yield a polymeric precipitate. Water-soluble impurities were separated from the precipitate using ultra-filtration and finally the NAC-HCPS was obtained as a white powder after lyophilisation (Ishihara et al, 2000a). The weight fraction of NAC-Hep (non-reduced $\mathrm{IO}_{4}{ }^{-}$
LMW-Hep) component in the NAC-HCPS was estimated to be $92 \%$ using a carbazole assay (Ishihara et al, 2001).

\section{Anti-coagulant activity}

Blood plasma was drawn from a femoral artery of a male New Zealand white rabbit (3 kg, Kitayama Labs Inc., Japan) anaesthetised with an intramuscular injection containing xylazine $(12 \mathrm{mg})$ and ketamin $(40 \mathrm{mg})$. The indicated concentration of native Hep, $\mathrm{IO}_{4}$-Hep, $\mathrm{IO}_{4}$-LMW-Hep or NAC-HCPS was added to $10 \mathrm{ml}$ of plasma, and the activated partial thromboplastin time (APTT) and prothrombin time (PT) were determined.

\section{Cell culture}

Lewis lung cancer cells (3LL) were obtained from the Cancer Cell Repository (CCR) Institute of Development, Aging and Cancer Tohoku University, Sendai, Japan. B16 melanoma cells (B16) were obtained from the RIKEN Cell Bank, Saitama, Japan. These malignant cells and fibroblasts (human dermal fibroblast, Takara Biochemical Corp. Ohtsu, Japan) were grown in Dulbecco's modified Eagle's medium (DMEM, Life Technologies Oriental Inc., Tokyo, Japan) supplemented with $10 \%$ heat-inactivated feotal bovine serum (FBS), antibiotics (100 $\mathrm{U} \mathrm{ml}^{-1}$ penicillin $\mathrm{G}$ and $100 \mu \mathrm{g} \mathrm{ml}^{-1}$ streptomycin) under the atmosphere of $5 \% \mathrm{CO}_{2}$ in air and $100 \%$ relative humidity. Human microvascular endothelial cells (HMVEC, Takara Biochemical Corp., Ohtsu, Japan) were grown in medium 199 (Life Technologies Oriental Inc., Tokyo, Japan) supplemented with 10\% heat-inactivated FBS, antibiotics $\left(100 \mathrm{U} \mathrm{ml}^{-1}\right.$ penicillin $\mathrm{G}$ and $100 \mu \mathrm{g} \mathrm{ml}^{-1}$ streptomycin) and $10 \mathrm{ng} \mathrm{ml}^{-1}$ fibroblast growth factor-2 (FGF-2, R\&D Systems, Minneapolis, MN, USA). The cells used in this study were between the 4 th and 8th passage.

\section{Cell growth assay in vitro}

Fibroblasts, 3LL and B16 cells $\left(5 \times 10^{3}\right.$ per well $)$ were seeded on 96well tissue culture plates (Falcon) in $100 \mu \mathrm{l}$ of DMEM containing the same FBS and antibiotics as mentioned above, as well as the indicated concentration of either Hep, $\mathrm{IO}_{4}$-Hep, $\mathrm{IO}_{4}$-LMW-Hep or NAC-HCPS, and grown for 3 days. Human microvascular endothelial cells $\left(5 \times 10^{3}\right.$ per well $)$ were seeded on 96 -well tissue culture plates in $100 \mu \mathrm{l}$ of medium 199, containing (i) the same FBS and antibiotics as mentioned above, (ii) the indicated concentration of either Hep, $\mathrm{IO}_{4}$-Hep, $\mathrm{IO}_{4}$-LMW-Hep or NAC-HCPS, and (iii) one of the growth factors (either $4 \mathrm{ng} \mathrm{ml}^{-1}$ of VEGF 165 , $10 \mathrm{ng} \mathrm{ml}^{-1}$ of FGF-2 or $20 \mathrm{ng} \mathrm{ml}^{-1}$ of HGF), and grown for 5 days. After incubation, the depleted medium was replaced with $100 \mu \mathrm{l}$ of fresh medium including $10 \mu \mathrm{l}$ of WST-1 reagent (Cell Counting Kit, Dojindo, Kumamoto, Japan) was added to each well, and the optical density (OD) was read at $450 \mathrm{~nm}$ in an Immuno Mini plate reader (Nunc InterMed Japan, Tokyo) after $1 \mathrm{~h}$ incubation at $37^{\circ} \mathrm{C}$. Results are expressed as percentage, using the mean value of controls (without any heparinoid).

\section{Cell adhesion onto Matrigel-coated plate}

Human microvascular endothelial cells $\left(1 \times 10^{5}\right.$ cells per well $)$ were plated on a Matrigel (20 $\mu$ l of $0.5 \%$ DMEM solution per well, Collaborative Biomedical Products, Two Oak Park, Bedford, MA, USA) coated 24-well tissue culture plate in $1 \mathrm{ml}$ of medium 199, containing the same FBS, antibiotics and the indicated concentration of either Hep, $\mathrm{IO}_{4}$-Hep, $\mathrm{IO}_{4}$-LMW-Hep or NAC-HCPS without $10 \mathrm{mg} \mathrm{ml}^{-1}$ FGF-2. Similarly B16 and 3LL cells $\left(1 \times 10^{5}\right.$ cells per well $)$ were plated on the Matrigel-coated 24 -well tissue culture plate in DMEM, containing the same FBS, antibiotics and the indicated concentration of either $\mathrm{Hep}, \mathrm{IO}_{4}-\mathrm{Hep}, \mathrm{IO}_{4}{ }^{-}$ LMW-Hep or NAC-HCPS. After $1 \mathrm{~h}$ incubation, the used medium was removed and the Matrigel-coated wells were gently rinsed five 

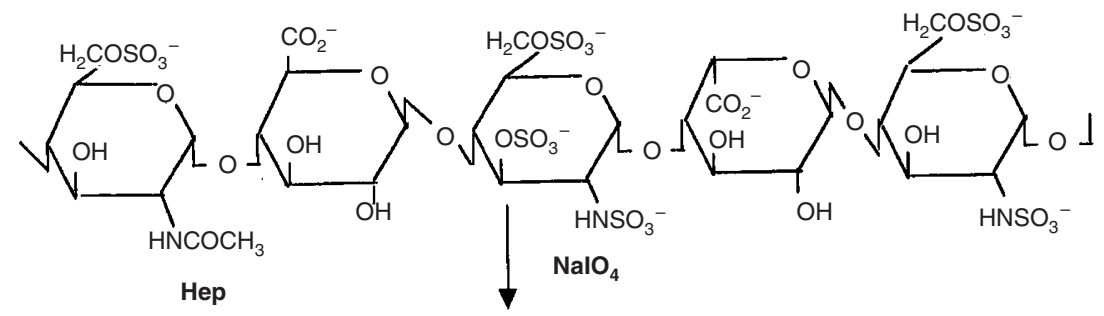

$\mathrm{H} \mathrm{COSO}_{3}^{-}$

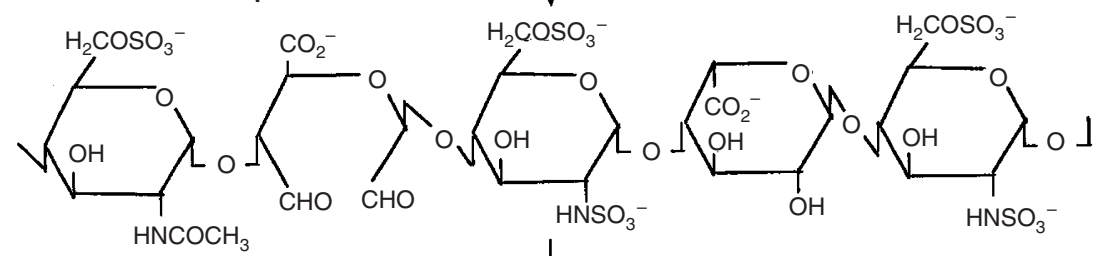

non-reduced $\mathrm{IO}_{4}$-Hep

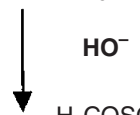

$\mathrm{HO}^{-}$

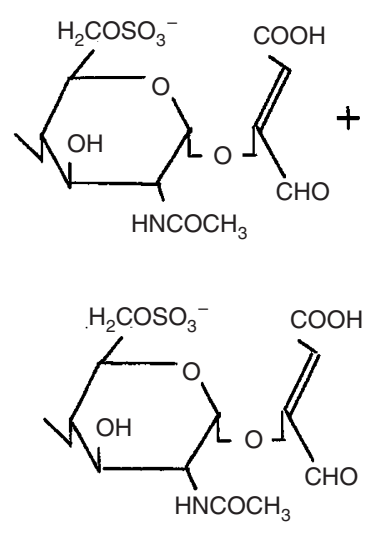

non-reduced $\mathrm{IO}_{4} \mathrm{LMW}$-Hep
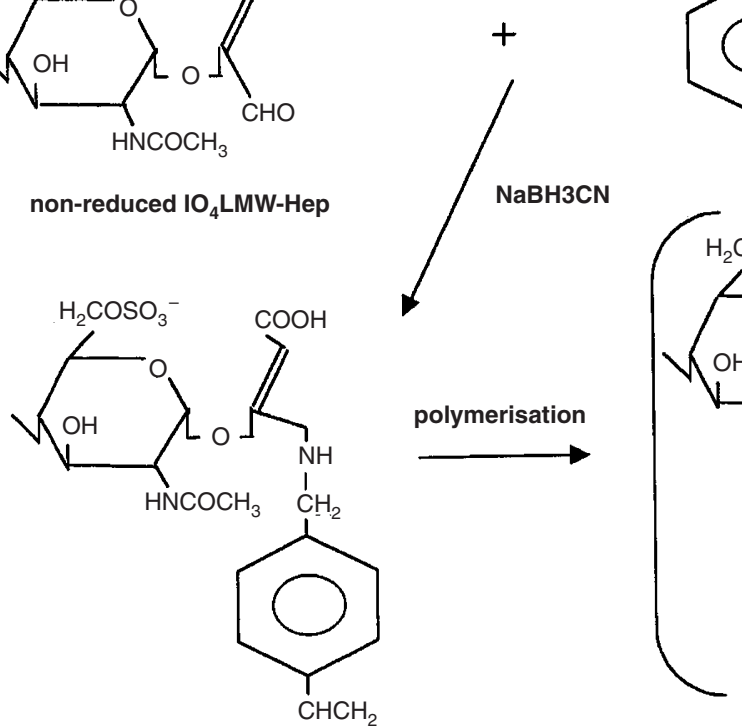

(1)

$\mathrm{N}$-p-vinylbenzylamine<smiles>Cc1ccc(CN)cc1</smiles>

H

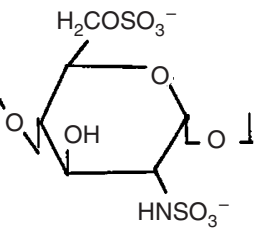

dialysis

$\mathrm{H}_{2} \mathrm{COSO}_{3}^{-}$

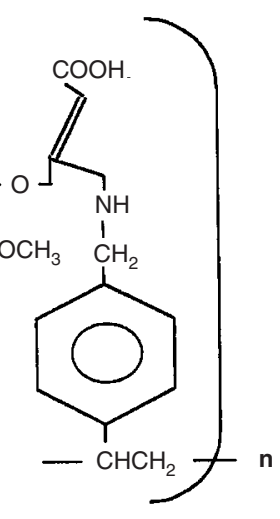

NAC-HCPS

Figure I Reaction scheme for the preparation of $1 \mathrm{O}_{4}-\mathrm{Hep}, 1 \mathrm{O}_{4}-\mathrm{LMW}-\mathrm{Hep}$ and NAC-HCPS.

times with PBS to remove non-binding cells. The fresh medium $(450 \mu \mathrm{l})$ and $50 \mu \mathrm{l}$ of WST-1 reagent (cell counting kit; Dojindo) was added to each well, and the optical density (OD) of the medium was measured at $450 \mathrm{~nm}$ in the Immuno Mini plate reader after $1 \mathrm{~h}$ incubation at $37^{\circ} \mathrm{C}$.

\section{Tubular formation of HMVECs}

Human microvascular endothelial cells $\left(5 \times 10^{4}\right.$ cells per well $)$ were seeded on a Matrigel- ( $50 \mu \mathrm{l}$ of $1 \%$ DMEM solution per well) coated 96-well tissue culture plate in $100 \mu$ of medium 199, containing the same FBS, antibiotics without $10 \mathrm{ng} \mathrm{ml}^{-1} \mathrm{FGF}-2$, and the indicated concentration of either Hep, $\mathrm{IO}_{4}$-Hep, $\mathrm{IO}_{4}$-LMW-Hep or NACHCPS as given above. After $8 \mathrm{~h}$ incubation, the formation of tube-like structures by HMVEC was examined microscopically and photographed at $\times 100$ magnification. These micrographs were scanned with a film scanner and analysed using an image analyser (NIH Image, Ver. 1.60, NIH, Bethesda. MD, USA). The total length of a tube-like structure was expressed as percentage of the mean value and related to control without any heparinoid.

\section{Tumour cell invasion assay}

The effect of NAC-HCPS on the invasion activity of tumour cells was also evaluated using a growth factor-reduced Matrigel invasion chamber (for a 24 -well plate, $8 \mu \mathrm{m}$ pore size, Becton Dickinson Labware, Bedford, MA, USA) according to the method described by Albini et al (1987) with some minor modifications. Briefly, fresh 
media (DMEM, $0.75 \mathrm{ml}$ ) containing $0.1 \mathrm{wt} \% \mathrm{BSA}, 10 \mathrm{wt} \% \mathrm{FBS}$ as a chemo-attractant, and the indicated concentration of either Hep, $\mathrm{IO}_{4}$-Hep, $\mathrm{IO}_{4}$-LMW-Hep, or NAC-HCPS were added to the wells of the plate (the lower chamber). The upper chamber had been pre-coated with Matrigel by the manufacturer. Tumour (3LL or B16) cells were suspended in DMEM containing 0.1\% BSA and the indicated concentration of either $\mathrm{Hep}, \mathrm{IO}_{4}$-Hep, $\mathrm{IO}_{4}$-LMWHep or NAC-HCPS at a cell density of $5 \times 10^{4} \mathrm{cells} \mathrm{ml}^{-1}$, and the cell suspensions $(0.5 \mathrm{ml})$ were added into the upper chamber. After $18 \mathrm{~h}$ incubation, non-invading cells were gently removed from the upper surface of the membrane by wiping with a cotton swab. The invaded cells to the lower side of the membrane were stained with $0.4 \%$ Trypan blue solution and counted through microscopic observation. Invasion rates were calculated according to the following equation:

Invasion rate $(\%)=$ number of invading cells towards the lower membrane side/number of invading cells towards the lower membrane side without any heparinoid $\times 100$.

\section{Tumour growth in vivo}

Male C57BL/6 mice (6-7 weeks old) were purchased from Clea Japan Inc., Tokyo, Japan. Tumour (3LL or B16) cells were trypsinised and suspended in Hanks' balanced salt solution (HBSS). Tumour cells $\left(1 \times 10^{7}\right)$ in $100 \mu \mathrm{l}$ of HBSS were implanted into the dorsal subcutis of the mice. After tumours had reached to a volume of $100 \sim 200 \mathrm{~mm}^{3}$ around 14 days (defined as day 1), $200 \mu \mathrm{l}$ of $\mathrm{IO}_{4^{-}}$ Hep, $\mathrm{IO}_{4}$-LMW-Hep or NAC-HCPS (each $10 \mathrm{mg} \mathrm{ml}^{-1}$ of PBS solution) was subcutaneously administered around the tumour daily for another 6 days. Control mice were administered the same volume of only PBS (200 $\mu$ l per injection). The size of a tumour on day 1 and day 8 was measured with calipers and tumour volume was estimated as length $\times$ width $\times$ height $\times \pi / 6$. The growth rate of a tumour was then calculated as volume (day 8 )/volume (day 1 ). The $3 \mathrm{LL}$ and B16 tumour volumes of control on day 8 were $3200 \pm 400$ and $4300 \pm 500 \mathrm{~mm}^{3}$, respectively. Each experimental group was composed of eight mice. Data were compared with the mean volume of the PBS treated group (represented as 100\%).

\section{Vascularity of the tumour}

The NAC-HCPS-treated and control tumours of 3LL cells on day 8 were fixed in $10 \%$ neutral buffered formaldehyde, and embedded in paraffin for immuno-histochemical study. To evaluate the microvessel density of the tumour, CD34 as an endothelial cell (vessel) marker was stained by an indirect method (Tomisawa et al, 1999; Oshika et al, 2000). After each section ( $4 \mu \mathrm{m}$ thick) was dehydrated and treated with $0.6 \%$ hydrogen peroxide in methanol for $45 \mathrm{~min}$, slides were autoclaved for antigen retrieval $\left(121^{\circ} \mathrm{C}\right.$ $15 \mathrm{~min}$ ). Slides were then incubated with $5 \%$ normal goat serum for $60 \mathrm{~min}$ and reacted with rat anti-murine CD34 monoclonal antibody $(1: 20$, Hycult Biotechnology, Uden, The Netherlands) at $4{ }^{\circ} \mathrm{C}$, overnight. Peroxidase-conjugated anti-rat $\operatorname{IgG}(1: 200$, Amersham Life Science, Buckinghamshire, UK) was used as the second antibody at room temperature for $60 \mathrm{~min}$ and the interactions were visualised with 3,3'-diaminobenzidine-chromogen (DAKO Japan, Kyoto). Finally, nuclear counterstaining was carried out with Mayer's haematoxylin. In each section, five randomised areas (microscopic fields, $\times 100$ magnificant) that were considered to show the largest vessel density, were photographed, and CD34stained vessels were counted. Each experimental group was composed of six mice. Data have been compared with the average value in PBS treated tumours, defined as $100 \%$.

\section{Experimental metastasis}

Mice were injected intravenously with $3 \times 10^{5}$ cells of either $3 \mathrm{LL}$ or $\mathrm{B} 16$ cells in $100 \mu \mathrm{l}$ PBS through a lateral tail vein. From day 1 to day 7, either $\mathrm{IO}_{4}$-Hep, $\mathrm{IO}_{4}$-LMW-Hep or HCPS ( $1 \mathrm{mg}$ per $100 \mu \mathrm{l}$ PBS) or $100 \mu$ of PBS only was administered intraveneously once a day. All mice were sacrificed day 14 after the tumour cells were injected, and the lungs of each mouse were removed. Lungs were then fixed in Bouin's solution overnight and the surface tumour nodules were counted under a stereoscopic microscope. The numbers of $3 \mathrm{LL}$ and B16 tumour nodules in control (PBS-treated) were $250 \pm 50$ per mouse and $180 \pm 30$ per mouse, respectively. Each experimental group was composed of eight mice. Data were evaluated against the mean values of the PBS treated group (represented as $100 \%)$.

\section{Statistical analysis}

All summarised data are expressed as the mean value \pm s.e. Comparisons between means of multiple groups were analysed by one-way analysis of variance and Scheffe's multiple comparisons test. All statistical analyses were carried out using the StatView (version 5.0) statistical package (Abacus Concepts Inc., Berkeley, CA, USA). All animal experiments have been carried out with ethical committee approval of the National Defense Medical College, Tokorozawa, Saitama, Japan. The ethical guidelines that were followed meet the standards required by Cancer Research UK guidelines (Workman et al, 1998).

\section{RESULTS}

\section{Anti-coagulant activity of NAC-HCPS}

Addition of each $\mathrm{Hep}, \mathrm{IO}_{4}$-Hep, $\mathrm{IO}_{4}$-LMW-Hep, and NAC-HCPS prolonged the coagulation time of rabbit plasma in a dose-dependent manner (Figure 2A, APTT). APTT of the rabbit plasma
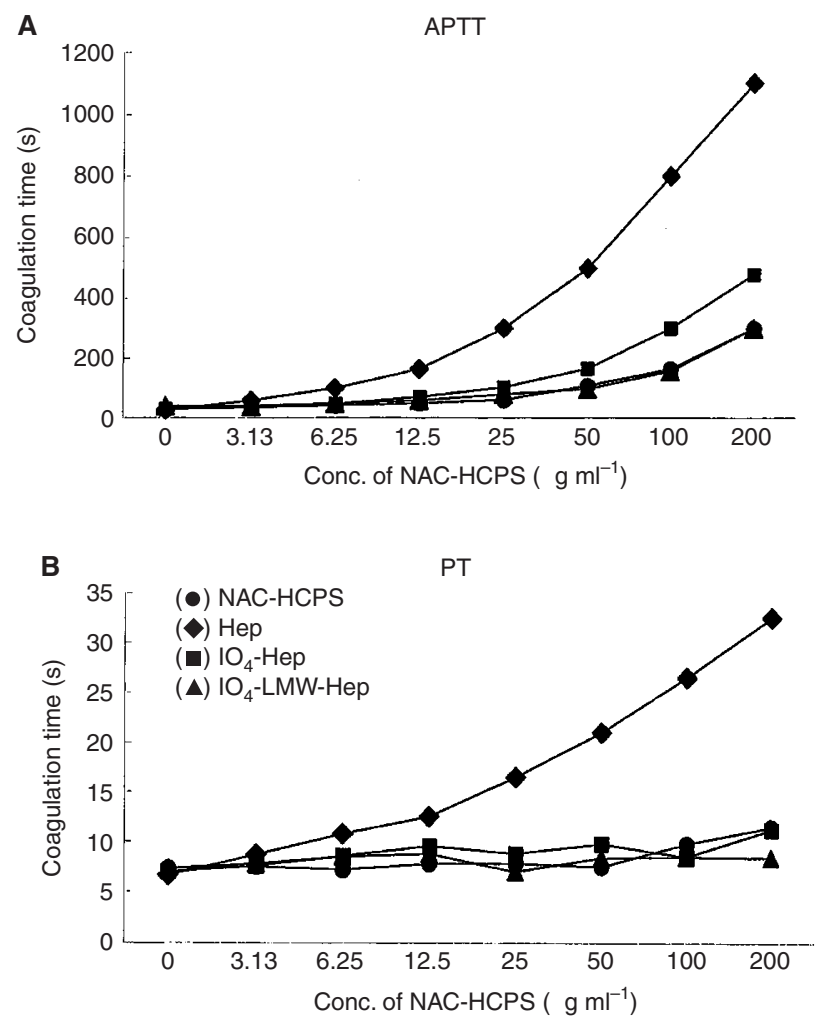

Figure 2 Anticoagulant activity of NAC-HCPS. APTT $(\mathbf{A})$ and PT $(\mathbf{B})$ of rabbit plasma containing various concentrations of NAC-HCPS, $\mathrm{Hep}_{1} \mathrm{IO}_{4}$ Hep and $\mathrm{IO}_{4}$-LMW-Hep were measured, as has been described in Materials and Methods. 
without any heparinoids was about $30 \mathrm{~s}$. At a concentration of $100 \mu \mathrm{g} \mathrm{ml}^{-1}$, Hep greatly prolonged APTT to about $800 \mathrm{~s}$, while $\mathrm{IO}_{4}$-Hep, $\mathrm{IO}_{4}$-LMW-Hep and NAC-HCPS prolonged APTT to about 300, 160 and $160 \mathrm{~s}$, respectively. As shown in Figure 2B, the PT of rabbit plasma without any heparinoid is about $7 \mathrm{~s}$. While Hep strongly prolonged PT to about $27 \mathrm{~s}$ at the concentration of $100 \mu \mathrm{g} \mathrm{ml}^{-1}, \mathrm{IO}_{4}$-Hep, $\mathrm{IO}_{4}$-LMW-Hep and NAC-HCPS only prolonged the PT to 8 to $10 \mathrm{~s}$. Since the periodate oxidation of Hep is known to destruct a penta-saccharide structure which interacts with antithrombin III (Conrad and Guo, 1991), the remainder of the anticoagulant activities of $\mathrm{IO}_{4}-\mathrm{Hep}, \mathrm{IO}_{4}$-LMW-Hep and NAC-HCPS may result from interactions with other anticoagulant factors, such as heparin co-factor II (Bourin and Lindahl, 1993).

\section{Effect of NAC-HCPS on cell growth in vitro}

Human microvascular endothelial cells were able to grow in medium in the presence of $10 \%$ FBS without addition of a specific growth factor. When $\mathrm{VEGF}_{165}, \mathrm{FGF}$ and HGF were added to the culture medium, the growth rate of HMVEC increased to 1.2-1.7-fold when compared to the control. Horizontal lines in Figure 3A,B,C show the level of cell growth in DMEM containing 10\% FBS in the absence of exogenous growth factors. While addition of low concentrations (below $8 \mu \mathrm{g} \mathrm{ml}^{-1}$ ) of $\mathrm{Hep}, \mathrm{IO}_{4}$-Hep or $\mathrm{IO}_{4}$-LMW-Hep to the medium did not influence the growth of HMVEC in the presence of each growth factor, high concentrations (more than $32 \mu \mathrm{g} \mathrm{ml}^{-1}$ ) slightly inhibited the growth in a dose-dependent manner (Figure $3 \mathrm{~A}, \mathrm{~B}, \mathrm{C})$. On the other hand, NAC-HCPS inhibited the growth factor-induced HMVEC growth in a dose-dependent manner, even at low concentrations $\left(<2 \mu \mathrm{g} \mathrm{ml}^{-1}\right)$.

The doubling times of fibroblast and 3LL cell growth in DMEM containing $10 \%$ FBS and antibiotics were 25 and $17 \mathrm{~h}$, respectively, and the cell growth was not influenced upon addition of either Hep, $\mathrm{IO}_{4}$-Hep, $\mathrm{IO}_{4}$-LMW-Hep or NAC-HCPS up to $500 \mu \mathrm{g} \mathrm{ml} \mathrm{g}^{-1}$ (Figure 4A,B). However, only NAC-HCPS inhibited B16 cell growth in a dose-dependent manner (Figure 4C). The doubling time of B16 cell growth in the control culture and $500 \mu \mathrm{g} \mathrm{ml}^{-1}$ NAC-HCPS containing culture were 18 and $23 \mathrm{~h}$, respectively.

\section{Effect of NAC-HCPS on tubular formation of HMVECs}

Human microvascular endothelial cells are well known to form capillary-like tubular structures when seeded on Matrigel (Collen et al, 2000). The effect of NAC-HCPS in culture media on this tubular formation of HMVEC was compared to that of Hep, $\mathrm{IO}_{4}$-Hep and $\mathrm{IO}_{4}$-LMW-Hep. Figure 5A shows representative microphotographs of tubular formation of HMVEC cultured in the presence of respectively 2 or $32 \mu \mathrm{g} \mathrm{ml}^{-1}$ of NAC-HCPS, Hep, $\mathrm{IO}_{4}-\mathrm{Hep}$ and $\mathrm{IO}_{4}$-LMW-Hep. While Hep, $\mathrm{IO}_{4}$-Hep, and $\mathrm{IO}_{4}$-LMW-Hep showed a low inhibitory effect on the tubular formation up to concentrations of $100 \mu \mathrm{g} \mathrm{ml}^{-1}$ (Figure 5B), NAC-HCPS exhibited a strong inhibition on the tubular formation, even at low concentration $\left(2 \mu \mathrm{g} \mathrm{ml}^{-1}\right.$, Figure $\left.5 \mathrm{~A}, \mathrm{~B}\right)$.

\section{Effect of NAC-HCPS on tumour cell invasion}

The inhibitory effect of NAC-HCPS on the migration and invasion of tumour cells (3LL and B16) was examined using a Matrigel invasion chamber (Albini et al, 1987). When 3LL and B16 cells were cultured on the Matrigel invasion chamber without any heparinoid, about 200 and 80 cells were invaded into the lower side of the membrane, respectively. While both cell types showed a slightly enhanced invasive activity in the presence of $4 \mu \mathrm{g} \mathrm{ml}^{-1}$ of $\mathrm{Hep}, \mathrm{IO}_{4}-\mathrm{Hep}$, and $\mathrm{IO}_{4}$-LMW-Hep, the invasive activities were reduced in the presence of high concentrations $\left(100 \mu \mathrm{g} \mathrm{ml}^{-1}\right)$ of Hep, $\mathrm{IO}_{4}-\mathrm{Hep}$, and $\mathrm{IO}_{4}$-LMW-Hep (Figure 6A,B). On the other hand, the invasive activity of both cell types in the presence of

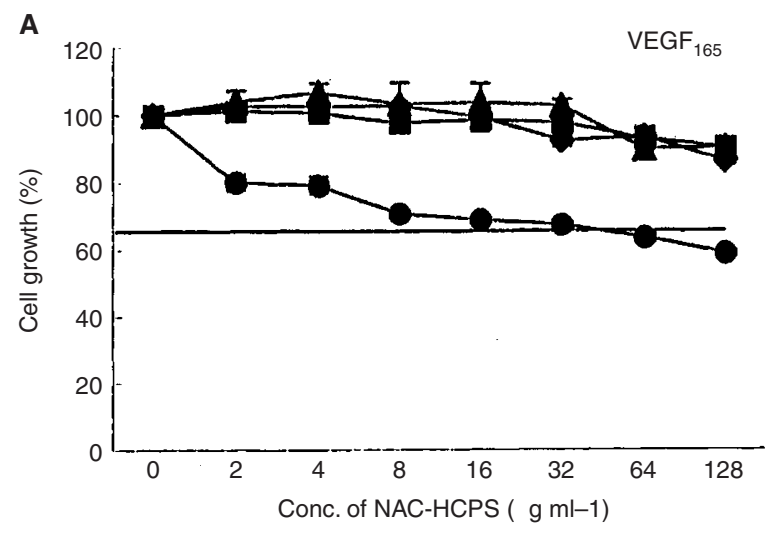

B

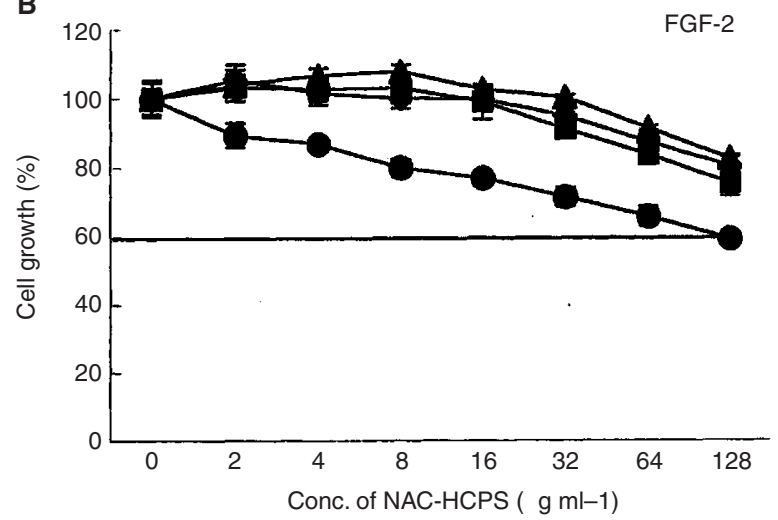

C

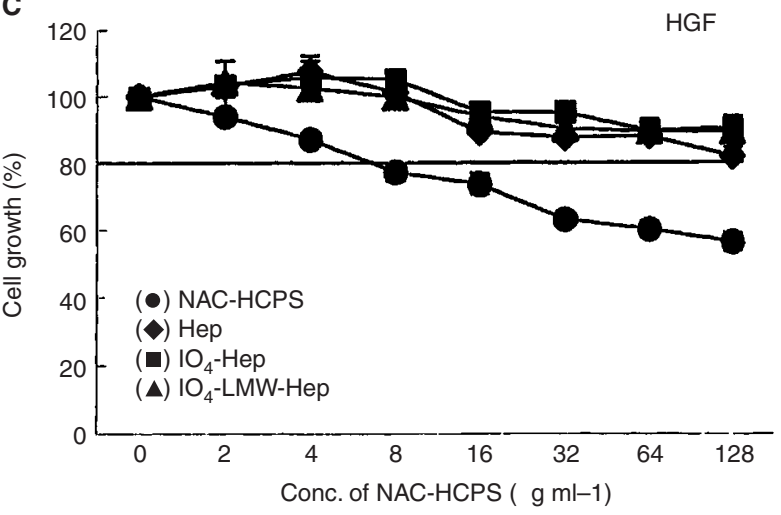

Figure 3 Effect of NAC-HCPS on growth factor-stimulated HMVEC growth. (A) VEGF 165 , (B) FGF-2, (C) HGF. Cell growth incubated with a growth factor in the absence of heparinoid was defined as $100 \%$ growth, and the data were calculated as a percentage. The horizontal line in each panel represents the level of cell growth obtained in the absence of both growth factor and heparinoid. The results represent the mean \pm s.e. in triplicate.

NAC-HCPS was strongly inhibited, even at a low concentration $\left(4 \mu \mathrm{g} \mathrm{ml}^{-1}\right)$. Therefore, it is suggested that NAC-HCPS possesses an anti-invasive activity for tumour cells.

\section{Effect of NAC-HCPS on endothelial and tumour cell adhesions to Matrigel-coated plates}

The adhesions of HMVECs and tumour cells (3LL and B16) to Matrigel-coated plates may be an important first step in the tubular formation of HMVECs on the Matrigel, as well as tumour cell invasion through the Matrigel invasion chamber, respectively. We 

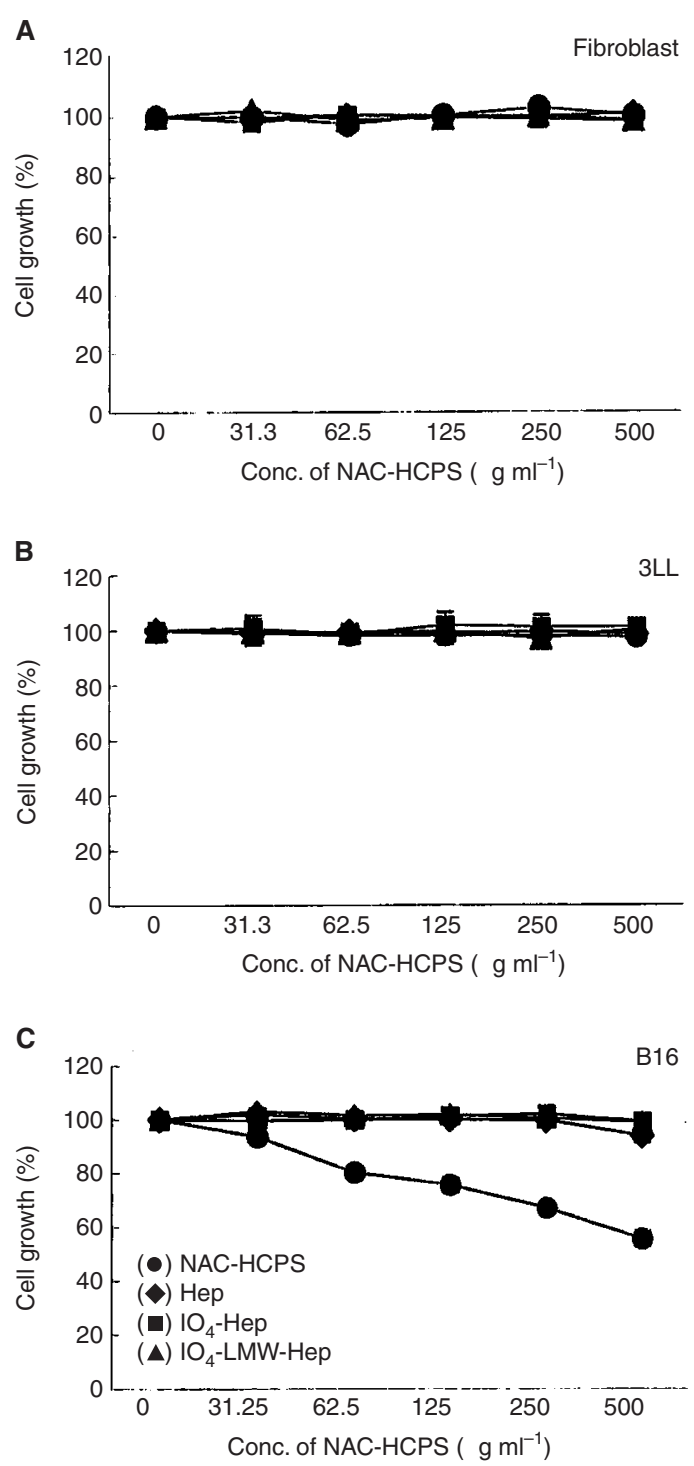

Figure 4 Effect of NAC-HCPS on fibroblast, 3LL and BI6 cell growths. The cell growth in the absence of heparinoid was defined as 100\% growth, and the data were calculated as a percentage. The results represent the mean \pm s.e. in triplicate.

examined the effect of NAC-HCPS on both HMVEC and tumour cell adhesion to Matrigel-coated plates. All HMVEC, 3LL and B16 cells adhered to the Matrigel-coated plates within $1 \mathrm{~h}$ in the absence of NAC-HCPS (Figure 7) showing spreading shapes on the surface. On the other hand, NAC-HCPS inhibited adhesion of all the HMVEC, 3LL and B16 cells to the Matrigel-coated plates in a concentration-dependent manner (Figure 7). Furthermore, almost all cells of these three cell types retained their spherical shapes in the presence of high concentrations of NAC-HCPS (20 and $100 \mu \mathrm{g} \mathrm{ml}^{-1}$ ) up to $5 \mathrm{~h}$ (data not shown). However, neither Hep, $\mathrm{IO}_{4}$-Hep nor $\mathrm{IO}_{4}$-LMW-Hep showed the cell shape-retaining effect.

\section{Effect of NAC-HCPS on tumour growth in vivo}

A measurable tumour (tumour volume: $100 \sim 200 \mathrm{~mm}^{3}$ ) was formed 14 days after implantation of tumour cells (3LL or B16). As shown in Figure $8 \mathrm{~A}, \mathrm{IO}_{4}$-Hep and $\mathrm{IO}_{4}$ - $\mathrm{LMW}$-Hep reduced subcutaneous induced tumour growth of $3 \mathrm{LL}$ cells to various
A

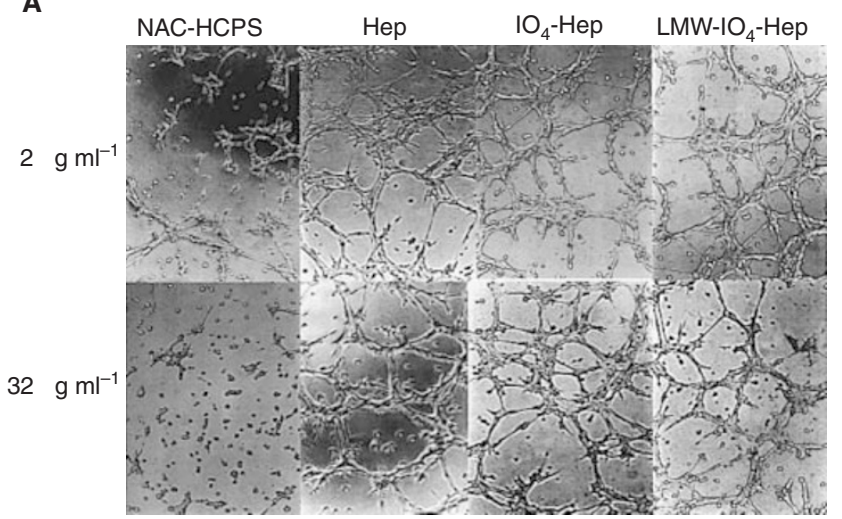

B

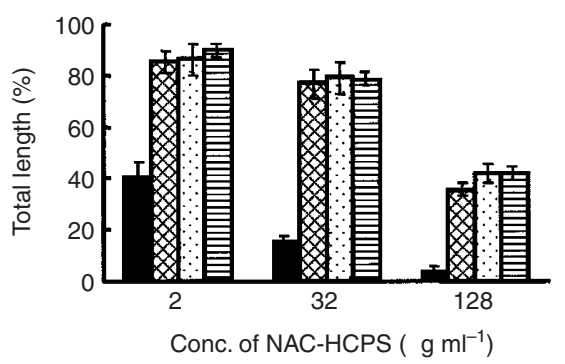

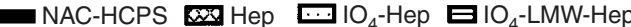

Figure 5 Effect of NAC-HCPS on tubular formation of HMVEC. (A) Photomicrographs (original magnification: $\times 100$ ) of the tubular formation of HMVEC cultured with 2 or $32 \mu \mathrm{g} \mathrm{ml}{ }^{-1}$ of NAC-HCPS, Hep, IO ${ }_{4}-\mathrm{Hep}$ and $\mathrm{IO}_{4}$-LMW-Hep for $8 \mathrm{~h}$ on Matrigel-coated plates. Results are representatives of three independent experiments. (B) The quantitative evaluations of tubular formation of HMVEC cultured with various concentrations of NAC-HCPS, Hep, IO ${ }_{4}$-Hep and $\mathrm{IO}_{4}$-LMW-Hep.

extents. NAC-HCPS more strongly inhibited tumour growth to about $40 \%$ of the PBS treated group $(P=0.0065$, vs PBS $)$ than $\mathrm{IO}_{4}$-Hep and $\mathrm{IO}_{4}$-LMW-Hep. On the other hand, while $\mathrm{IO}_{4}-\mathrm{Hep}$ and $\mathrm{IO}_{4}$-LMW-Hep did not significantly reduce the subcutaneous induced tumour growth of B16 melanoma (Figure 8B), NACHCPS significantly inhibited the tumour growth to about $10 \%$ of the PBS treated group $(P<0.0001$, vs PBS).

\section{Effect of NAC-HCPS on vascularity of the tumour in vivo}

To evaluate the effect of NAC-HCPS on anti-angiogenesis, immuno-histochemical staining of murine CD34 of NAC-HCPS treated and control tumours of 3LL cells were carried out (Tomisawa et al, 1999; Oshika et al, 2000). Representative microphotographs of CD34 immuno-localisation in controls (PBS-treated) and NACHCPS treated subcutaneous induced tumours are shown in Figure 9A,B. In PBS treated mice, many CD34 positive stained vessels were diffusely located and clearly formed tube-like structures in the tumour. On the other hand, CD34 positive stained vessels were nearly absent in the NAC-HCPS treated tumours and tube-like structures were not observed. As shown in Figure 9C, NAC-HCPS significantly reduced the number of $\mathrm{CD} 34$ positive vessels $(P=0.0031)$, suggesting that NAC-HCPS significantly inhibited angiogenesis in tumours.

\section{Effect of NAC-HCPS on experimental metastasis}

To evaluate the inhibitory effect of NAC-HCPS on lung colony formation of tumour cells (3LL or B16), $\mathrm{IO}_{4}-\mathrm{LMW}-\mathrm{Hep}, \mathrm{IO}_{4^{-}}$ Hep and NAC-HCPS (each $1 \mathrm{mg}$ per $100 \mu \mathrm{l}$ PBS) was intrave- 
A

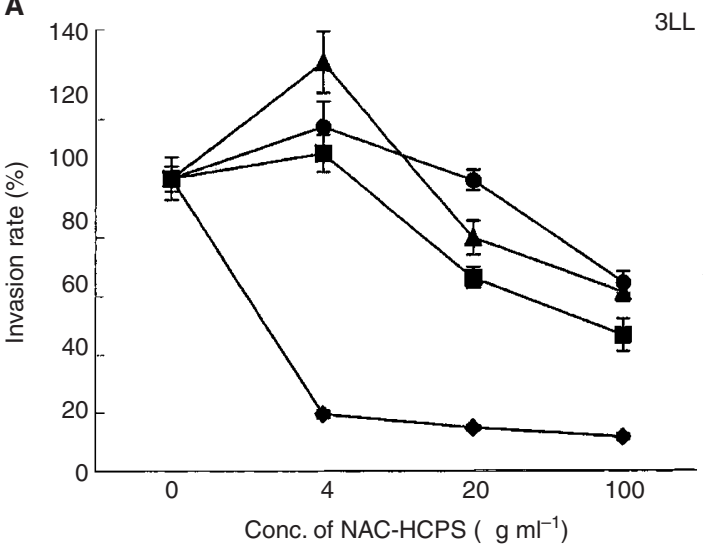

B

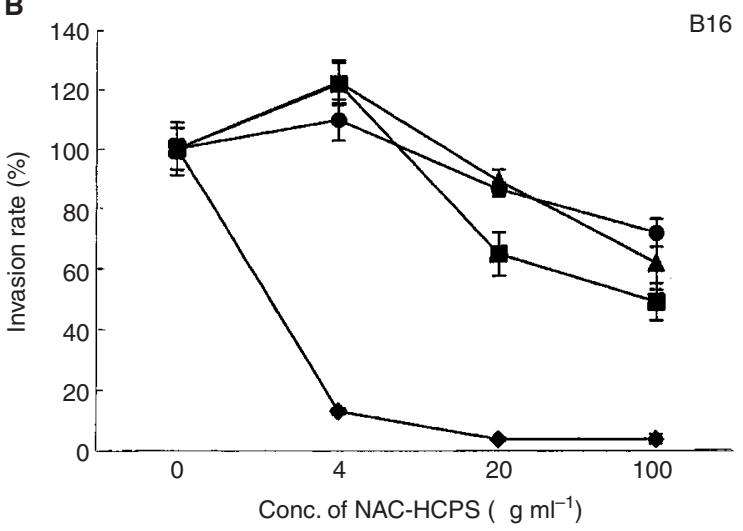

$\begin{array}{ll}\text { (•) NAC-HCPS } & (\boldsymbol{\bullet}) \mathrm{IO}_{4} \text {-Hep } \\ (\bullet) \mathrm{Hep} & (\boldsymbol{\Delta}) \mathrm{IO}_{4} \text {-LMW-Hep }\end{array}$

Figure 6 Effect of NAC-HCPS on tumour cell invasion. Tumour cells (3LL $(\mathbf{A})$ and Bl6 (B)) were seeded on a $8 \mu \mathrm{m}$ pore size membrane coated with Matrigel. After $18 \mathrm{~h}$ incubation, invaded cells were stained and counted. The invasion rates were calculated as described in Materials and Methods. Results represent the mean \pm s.e. of four independent determinations.

nously injected daily for 7 days after injection of the tumour cells. Therefore, Hep was excluded in this study. As shown in Figure $10 \mathrm{~A}, \mathrm{IO}_{4}$-LMW-Hep, $\mathrm{IO}_{4}$-Hep and NAC-HCPS inhibited lung colonisation of $3 \mathrm{LL}$ cells. Similarly in Figure $10 \mathrm{~B}$, all $\mathrm{IO}_{4}$-LMW$\mathrm{Hep}, \mathrm{IO}_{4}$-Hep and NAC-HCPS also showed lung colonisation inhibition of B16 cells. Furthermore, in $\mathrm{IO}_{4}$-LMW-Hep, $\mathrm{IO}_{4}$-Hep and PBS treated mice, a number of 3-20 tumour colonies of 3LL or B16 cells in liver were always observed in each mouse, while in NAC-HCPS treated mice, no colony formation of tumour cells in liver was observed (data not shown). Thus, NAC-Heps, especially NAC-HCPS, possess significant anti-metastasis activity of 3LL and B16 cells.

\section{DISCUSSION}

Heparin is clinically used as an antithrombotic agent, but its high dose use has been limited by its strong intrinsic anti-coagulant property itself, causing severe bleeding complications (Levine et al, 1989). If Hep could be modified to minimise its anti-coagulant property and to enhance its activities to inhibit tumour growth and metastasis, then such a modified Hep would be a very useful drug in treating malignant diseases. Periodate-oxidised $\left(\mathrm{IO}_{4^{-}}\right)$Hep and periodate-oxidised, alkaline-degraded low molecular weight $\left(\mathrm{IO}_{4^{-}}\right.$ LMW-) Hep (Fransson and Carlstedt, 1974; Fransson, 1978) are
A
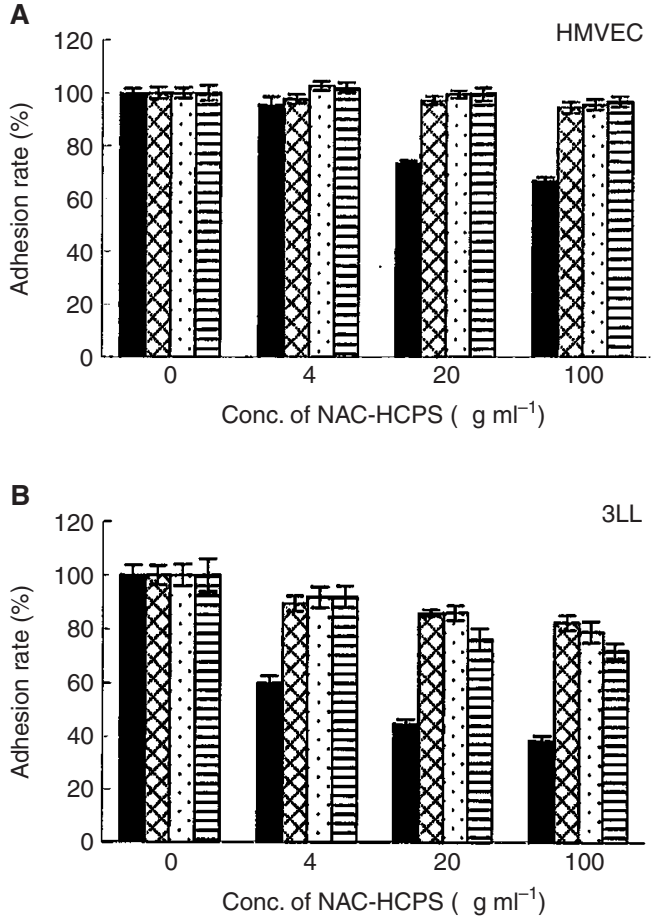

C

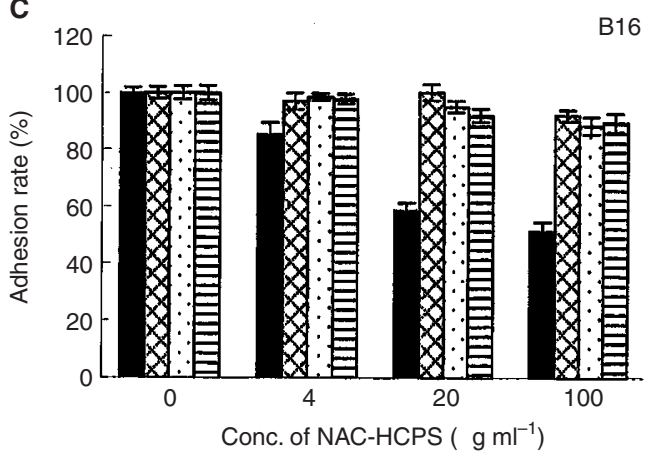

[NAC-HCPS $\mathrm{BHep} \square \mathrm{IO}_{4}$-Hep $\mathrm{EIO}$-LMW-Hep

Figure 7 Effect of NAC-HCPS on HMVEC, 3LL and BI6 cell adhesions on Matrigel-coated plates. HMVEC, $3 \mathrm{LL}$ and B 6 cells were plated on Matrigel-coated plates and incubated for $\mid \mathrm{h}$. The bound cells were quantified as described in Materials and Methods. The results represent the mean \pm s.e. in triplicate.

known for not having a specific pentasaccharide structure to interact with antithrombin III (Conrad and Guo, 1991), and therefore its anti-coagulant activity (APTT and PT) is much lower than Hep (Figure 2). We previously reported the preparation of NACHCPS using the $\mathrm{IO}_{4}$-LMW-Hep (Ishihara et al, 2000a). In this study, we have demonstrated that NAC-HCPS inhibits subcutaneously induced tumour growth and metastasis to lung of B16 melanoma and 3LL (Lewis lung cancer) cell line.

In the present study, NAC-HCPS when compared to Hep, $\mathrm{IO}_{4^{-}}$ Hep and $\mathrm{IO}_{4}$-LMW-Hep, has strong anti-angiogenic properties. This inhibitory effect of NAC-HCPS can not be ascribed to cytotoxicity, since it has been found that NAC-HCPS in concentrations up to $500 \mu \mathrm{g} \mathrm{ml}^{-1}$ do not inhibit the HMVEC growth in the absence of those growth factors (data not shown). NAC-HCPS inhibited the adhesion of HMVECs and tumour cells to the Matrigel-coated plate, as well as the tubular formation of 
3LL

A

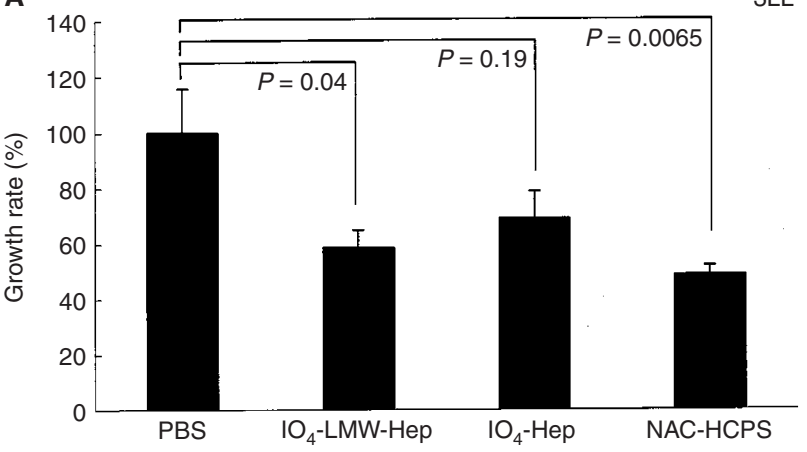

B16

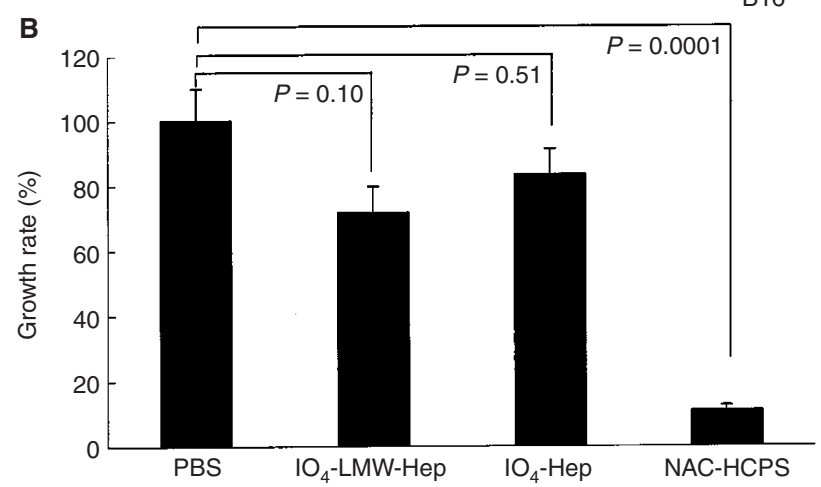

Figure 8 Effect of NAC-HCPS on subcutaneous induced tumour growth of $3 \mathrm{LL}(\mathbf{A})$ and $\mathrm{BI} 6(\mathbf{B})$ cells in mice. Tumour cells $\left(1 \times 10^{7}\right)$ were implanted into the dorsal subcutis of mice. After tumours reached a measurable size (I00 $200 \mathrm{~mm}^{3}$ ), $2 \mathrm{mg}$ per $200 \mu \mathrm{l}$ PBS of NAC-HCPS, IO Hep, $1 \mathrm{O}_{4}$-LMW-Hep or PBS $(200 \mu \mathrm{l})$ only was daily administered subcutaneously in the vicinity of the tumour for 7 days. Growth rates were calculated as described in Materials and Methods. Data were compared with the average tumour volume of the PBS treated group, defined as 100\%.

HMVEC on Matrigel. The inhibitory effect of NAC-HCPS is probably due to inhibition of the cell adhesion to the Matrigel as well as inhibition of heparin-binding growth factors. Moreover, endothelial cells in the extracellular matrix need binding to adhesive proteins to initiate invasion and migration (McCathy et al, 1990). Heparins, especially NAC-HCPS, can effectively bind to various adhesive proteins such as fibronectin, laminin and collagen, and thus may affect cell adhesion and tubular formation. Finally, NAC-HCPS markedly reduced the number of CD34-positive vessels (a marker of microvascular endothelial cells) in subcutaneous 3LL tumours (Tomisawa et al, 1999; Oshika et al, 2000). The above results demonstrate that NAC-HCPS with its reduced anticoagulant property has a strong anti-angiogenesis. This antiangiogenesis activity may be the explanation for the observed in vivo inhibition of experimental subcutaneous tumour growth.

In this study, it has been demonstrated that NAC-HCPS inhibits the adhesion of tumour cells to Matrigel-coated plates, probably due to the Hep-clustering effect of NAC-HCPS (Figure 7). In addition, immobilization of Hep onto Matrigel was important for the inhibitory effect of NAC-HCPS on tumour cell adhesion to Matrigel. As we reported previously, NAC-HCPS is effectively adsorbed to various polymeric surfaces (Ishihara et al, 2000a), collagen (type I)-substratum (Ishihara et al, 2001) and Matrigel (data not shown) through a hydrophobic interaction between the hydrophobic surface and polystyrene core of NAC-HCPS. And cell adhesion of tumour cells (B16 and 3LL) were similarly inhibited by immobilisation of NAC-HCPS on the Matrigel (data not shown).
A

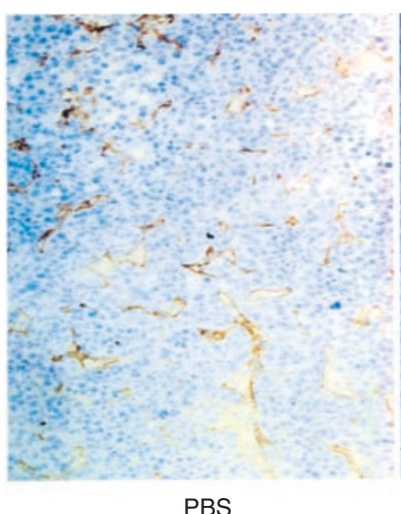

PBS
B

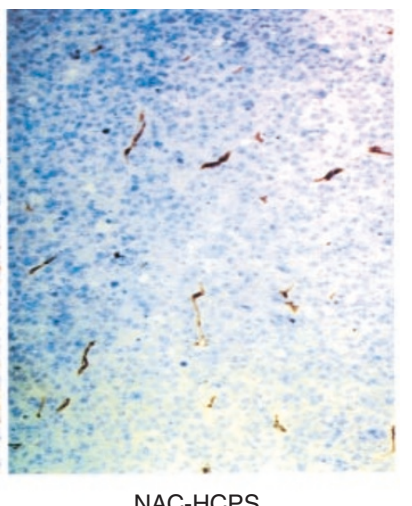

NAC-HCPS
C

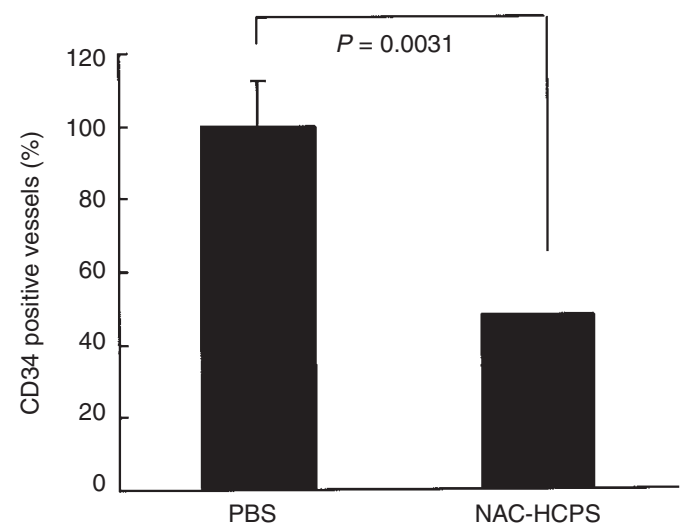

Figure 9 Effect of NAC-HCPS on 3LL-tumour vascularisation. Vascularisation of the 3LL-tumour, evaluated immuno-histochemically with antimurine CD34, markedly decreased in NAC-HCPS treated 3LL-tumours (B) when compared with PBS treated $3 \mathrm{LL}$-tumours $(\mathbf{A})$. The quantitative evaluation of the vascularisation $(\mathbf{C})$ was carried out as described in Materials and Methods.

Invasive properties are characteristic of malignant cells, and essential to tumour growth. Tumour cells use specific enzymes to solubilise extracellular matrix during tumour invasion. This degradation of the extracellular matrix takes place at highly localised regions in close vicinity to the cancer, where active proteolytic enzymes outbalance natural protease inhibitors present in the extracellular environment (Basbaum and Werb, 1996). These proteases are produced by either inflammatory cells, stromal cells or the tumour cell themselves (Liotta, 1992). Heparin, chemically modified heparins and related sulphated polysaccharides are known to be effective inhibitors for heparanase (Irimura et al, 1986; Vlodavsky et al, 1994; Lapierre et al, 1996) and various matrix metalloproteases (MMPs) including MMP-1, -2, -3 and -9 (Kenagy et al, 1994; Gogly et al, 1998). MMP-2 and -9 are suggested to play a major role in metastasis (Kugler, 1999; Westermarck and Kahari, 1999). Heparanase activity has also been found to correlate with the metastatic potential of various types of cancer cells (Nakajima et al, 1988). In this study the dose-dependent inhibition of NACHCPS on the invasion of tumour cells into Matrigel has been observed (Figure 6). It is possible that an enhanced inhibition of active proteolytic enzymes, as well as inhibition of adhesion of tumour cells to Matrigel by NAC-HCPS result in the strong inhibition of the tumour cell invasions. Tumour cell adhesion to subendothelial matrix and the subsequent invasion into the matrix are common pathways for tumour cells to escape from blood flow. 

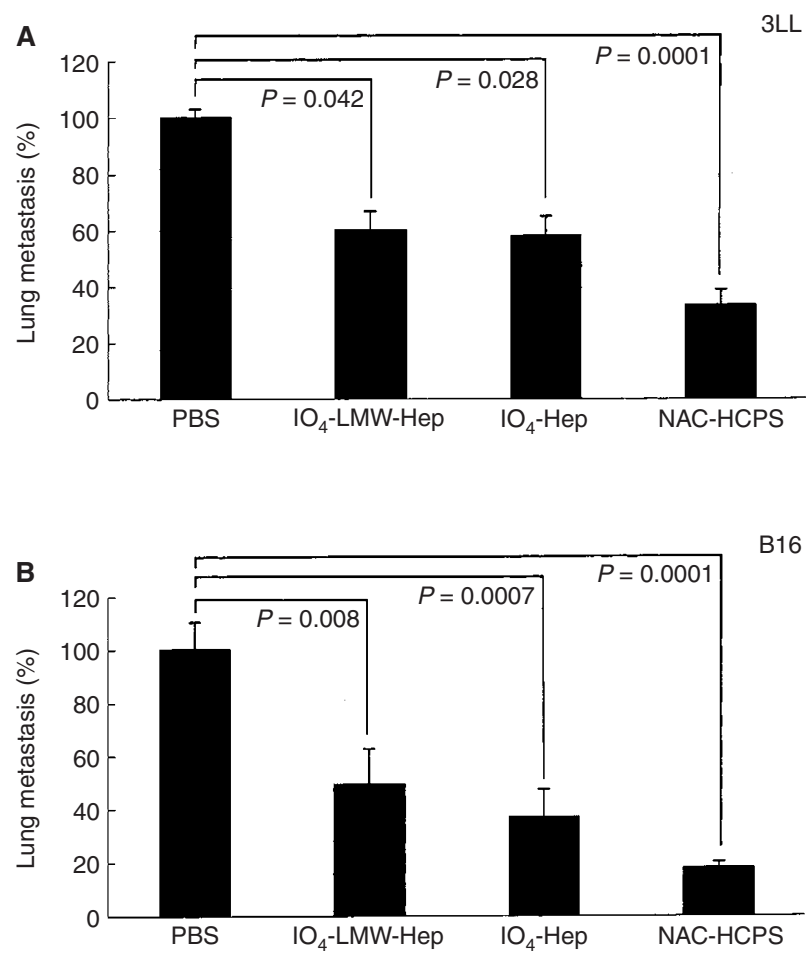

Figure 10 Effect of NAC-HCPS on lung colonisation of $3 \mathrm{LL}$ cells $(\mathbf{A})$ and $\mathrm{BI} 6$ cells $(\mathbf{B})$ in mice. Both tumour cells $\left(3 \times 10^{5}\right)$ were intraveneously injected through the lateral tail vein. From day I to day 7 , either NACHCPS, $1 \mathrm{O}_{4}-\mathrm{Hep}, 1 \mathrm{O}_{4}$-LMW-Hep (I mg per $100 \mu \mathrm{l}$ of PBS) or $100 \mu \mathrm{l}$ of PBS only was daily administered intraveneously through the lateral tail vein, and colony numbers on the lung surface in each mouse were counted on day 14.

\section{REFERENCES}

Albini A, Iwamoto Y, Kleinman HK, Martin GR, Aaroson SA, Kozlowski JM, McEwan RN (1987) A rapid in vitro assay for quantitating the invasion potential of tumour cells. Cancer Res 47: 3239-3245

Basbaum CB, Werb Z (1996) Focalized proteolysis: Spatial and temporal regulation of extracellular matrix degradation at the cell surface. Curr Opin Cell Biol 8: 731-738

Bourin MC, Lindahl U (1993) Glycosaminoglycans and the regulation of blood coagulation. Biochem J 289: 313-330

Collen A, Smorenburg SM, Peters E, Lupu F, Koolwijk P, Von Noorden C, Hinsbergh VWM (2000) Unfractionated and low molecular weight heparin affect fibrin structure and angiogenesis in vitro. Cancer Res 60: 6192-6200

Conrad HE, Guo Y (1991) Structural analysis of periodate-oxidized heparin. In Heparin And Related Polysaccharides, Advances in Experimental Medicine and Biology 313, Lane DA, Bjork I, Lindahl U (eds) pp 31-36. New York: Plenum Publishing

Costantini V, Zacharski LR (1992) The role of fibrin in tumour metastasis. Cancer Metastasis Rev 11: 283-290

Dvorak HF, Harvey VS, Estrella P, Brown LF, McDonagh J, Dvorak AM (1987) Fibrin containing gels induce angiogenesis. Implications for tumour stroma generation and wound healing. Lab Invest 57: 673-686

Engelberg H (1999) Actions of heparin that may affect the malignant process. Cancer 85: 257-272

Fransson L-A, Carlstedt I (1974) Alkaline and Smith degradation of oxidized dermatan sulphate-chondroirin sulphate copolymers. Carbohyr Res 36: $349-358$

Fransson L-A (1978) Periodate oxidation of the d-glucuronic acid residues in heparan sulphate and heparin. Carbohydr Res 62: 235-244

Gogly B, Hornebeck W, Groult N, Godeau G, Pellat B (1998) Influence of heparins on the interleukin-1-beta-induced expression of collagenase, stromelysin-1, and tissue inhibitor of metalloproteinase-1 in human gingival fibroblasts. Biochem Pharmacol 56: 1447-1454
The observed inhibition of metastasis by NAC-HCPS seems to be caused through the inhibition of adhesion and invasion of tumour cells (B16 and 3LL).

Our additional studies also have revealed that $\mathrm{IO}_{4}$-LMW-Hep and NAC-HCPS have about a 10 -fold smaller anticoagulant activity (APTT) than native Hep. The residual anticoagulant activity of NAC-HCPS is probably mediated by interaction with heparin cofactor II, and not antithrombin III (Conrad and Guo, 1991; Lapierre et al, 1996). In many tumour types, fibrin is a major component of the initial stroma (Costantini and Zacharski, 1992). Fibrin provides a scaffold for both invasive cancer and endothelial cells, thereby contributing to tumour growth and neo-vascularisation (Dvorak et al, 1987). The structure and mechanical properties of the fibrin matrix play a regulating role in the formation of capillary-like tubular structures (Nehls and Herrmann, 1996). Hep with its anticoagulant activity is thus expected to inhibit the formation of fibrin and microthrombi. Whether the low anticoagulant activity of NAC-HCPS contributes to its anti-tumour and anti-angiogenesis properties remains to be determined.

Compared with sulphated polysaccharides like Hep, NAC-HCPS has the advantage of exhibiting less toxicity due to its reduced anticoagulant activity. The subcutaneous haemorrhages were never observed in mice injected with the same amount of NAC-HCPS, and the NAC-HCPS treated mice lived longer. Furthermore, when $1 \mathrm{mg}$ of NAC-HCPS was intravenously injected daily for 7 consecutive days, only minor increases for the values of GOT (glutamicoxaloacetic transaminase), GPT (glutamic-pyruvic transaminase), BUN (blood urea nitrogen), and Crea (creatinine) were observed, returning to normal values within 7 days after the final injection (data not shown). However, sufficient data are not yet available of the complete toxicity profile of NAC-HCPS, and standard toxicologic and metabolic studies should be carried out in more detail to confirm the clinical safety of NAC-HCPS.
Irimura T, Nakajima M, Nicolson GL (1986) Chemically modified heparins as inhibitors of heparan sulfate specific endo-beta-glucuronidase (heparanase) of metastatic melanoma cells. Biochemistry 25: 5322-5328

Ishihara M, Ono K (1998) Structure and function of heparin and heparan sulfate: Heparinoid library and modification of FGF-activities. Trends Glycosci Glycotechnol 10: 223-233

Ishihara M, Saito Y, Ono K, Ishikawa K, Hattori H, Akaike T, Kurita A (2000a) Heparin-carrying polystyrene to mediate cellular attachment and growth via interaction with growth factors. J Biomed Mater Res 50: $144-152$

Ishihara M, Ono K, Ishikawa K, Hattori H, Saito Y, Yura H, Akaike T, Ozeki Y, Tanaka S, Mochizuki H, Kurita A (2000b) Enhanced ability of heparincarrying polystyrene (HCPS) to bind to heparin-binding growth factors and to inhibit growth factor-induced endothelial cell growth. $J$ Biochem 127: $797-803$

Ishihara M, Sato M, Hattori H, Saito Y, Yura H, Ono K, Masuoka K, Kikuchi M, Fujikawa K, Kurita A (2001) Heparin-carrying polystyrene (HCPS)bound collagen substratum to immobilize heparin-binding growth factors and to enhance cellular growth. J Biomed Mater Res 56: 536-544

Kenagy RD, Nikkari ST, Weigus HG, Clowes AW (1994) Heparin inhibits the induction of three matrix metalloproteases (stromelysin, $92 \mathrm{kD}$ gelatinase, and collagenase) in primate arterial smooth muscle cells. J Clin Invest 93: $1987-1993$

Kjellen L, Lindahl U (1991) Proteoglycans: Structure and interaction. Annu Rev Biochem 60: $443-475$

Kugler A (1999) Matrix metalloproteinases and their inhibitors. Anticancer Res 19: $1589-1592$

Lapierre F, Holme K, Lam L, Tressler RJ, Storm N, Wee J, Stack RJ, Castellot J, Tyrrell DJ (1996) Chemical modifications of heparin that diminish its anticoagulant but preserve its heparanase-inhibitory, angiostatic, antitumour and anti-metastatic properties. Glycobiology 6: 355-366 
Levine MN, Hirsh J, Kelton JG (1989) Heparin-induced bleeding. In Heparin: Chemical and Biological Properties, Clinical Applications, Lane DA, Lindahl U (eds) pp 517-531, Forida: CRC Press Inc

Lindahl U, Lidholt K, Spillmann D, Kjellen L (1994) More to heparin than anticoagulation. Thromb Res 75: $1-32$

Liotta LA (1992) Cancer cell invasion and metastasis. Sci Am 266: 54-59

McCathy JB, Skubitz AP, Qi Z, Mickelson DJ, Klein DJ, Furcht LT (1990) RGD-independent cell adhesion to the carboxy-terminal heparin-binding fragment of fibronectin involves heparin-dependent and -independent activities. J Cell Biol 110: 777-787

Nakajima M, Irimura T, Nicolson GL (1988) Heparanases and tumour metastasis. J Cell Biochem 36: $157-167$

Nehls V, Herrmann R (1996) The configuration of fibrin clots determined capillary morphogenesis and endothelial cell migration. Microvasc Res 51: $347-364$

Oshika Y, Nakamura M, Tokunaga T, Ohnishi Y, Abe Y, Tsuchida T, Tomii Y, Kijima H, Yamazaki H, Ozeki Y, Tomaoki N, Yamazaki H (2000) Ribozyme approach to downregulate vascular endothelial growth factor (VEGF) 189 expression in non-small cell lung cancer (NSCLC). Eur Cancer 36: $2390-2396$
Smorenburg SM, Van Noorden C (2001) The complex effects of heparins on cancer progression and metastasis in experimental studies. Pharmacol Rev 53: $93-105$

Tomisawa M, Tokunaga T, Oshika Y, Tsuchida T, Fukushima Y, Sato H, Kijima H, Yamazaki Y, Ueyama Y, Tamaoki N, Nakamura M (1999) Expression pattern of vascular endothelial growth factor isoform is closely correlated with tumour stage and vascularisation in renal cell carcinoma. Eur J Cancer 35: 133-137

Vlodavsky I, Mohsen M, Lider O, Svahn CM, Ekre HP, Vigoda M, IshaiMichaeli R, Peretz T (1994) Inhibition of tumour metastasis by heparanase inhibiting species of heparin. Invasion Metastasis 14: 290-302

Westermarck J, Kahari VM (1999) Regulation of matrix metalloproteinase expression in tumour invasion. FASEB J 13: 781-792

Workman P, Twentyman P, Balkwill F, Balmain A, Chaplin D, Double J, Embleton J, Newell D, Raymond R, Stables J, Stephens T, Wallace J (1998) United Kingdom Co-ordinating Committee on Cancer Research (UKCCCR) Guidelines for Welfare of Animals in Experimental Neoplasia (Second Edition). Br J Cancer 77: 1-10

Zacharski LR, Ornstein DL (1998) Heparin and cancer. Thromb Haemost 80: $10-23$ 